\title{
An Experimental Study of the Application of Cooperation Learning Teaching Mode in Optional Basketball Course
}

\author{
Guohua SHAO \\ Physical Education Institute of Inner Mongolia Normal University, Hohhot, Inner Mongolia
}

\begin{abstract}
Compared with the traditional cramming teaching method, the cooperation learning teaching mode is so different, for it is a new attempt to carry out the current PE teaching reform. This paper adopts the documentary and experimental method to study the application of cooperation learning teaching mode in optional basketball course. The results indicate that it has great advantages compared with the conventional teaching mode, for it could mobilize the enthusiasm of students, significantly improve the effectiveness of optional basketball course and provide a new way of thinking and theoretical basis for the teaching reform of college optional basketball course.
\end{abstract}

KEYWORD: Cooperation learning; Optional basketball course; Teaching; experiment

\section{INTRODUCTION}

As one of the optional courses in colleges and universities, basketball has features of strong participation and high entertainment, so it has won the appreciation of college students. With the increasing number of students who have chosen this optional course, the traditional teaching model has seriously hindered the enthusiasm of the students and the teaching effectiveness is not satisfying. Nowadays, most students are from the one-child families and they are often self-centered, lacking the initiative to actively participate in sports. Therefore, in the physical education, they are apt to compete rather than cooperate with each other, which has seriously affected their enthusiasm and ability to learn some technical movements. Basketball, a team sports, relies on the joint efforts of all the players. Therefore, how to cultivate students to do teamwork in sports activities and how to improve teaching effects of basketball have become the primary problem to be solved by the front-line teachers. The cooperation teaching model is in line with the actual situation of the current basketball teaching in colleges and universities.

The cooperation learning teaching mode in basketball teaching is based on the combination of teacher's guidance and multimedia learning. By watching the basketball instructional videos, students could learn the basic actions and principles, thus having a general idea of the basketball skills.

\section{RESEARCH METHODS}

\subsection{Literature}

Access to various literature about the cooperation learning teaching mode on CNKI and read related books, which provide a wealth of theoretical and experiment basis.

\subsection{Experimental Method}

The experiment is to test whether the cooperation learning teaching mode could arouse students' enthusiasm to learn basketball, improve their basic skills of basketball and enhance their companion relations and collective cohesion compared with the traditional teaching mode.

\subsubsection{Experimental Subjects}

Randomly select 70 students enrolled in 2013 from the Inner Mongolia Vocational College of Chemical Engineering as the experimental subjects, 35 students in the experimental group, 35 students in the control group.

\subsubsection{Experimental Design}

For the control group, the traditional teaching mode adopted, namely: demonstration-action decomposition-instruction-students' practice-error correction-students' practice. For the experimental group, the cooperation learning teaching mode is adopted, as is shown in Figure 1. 


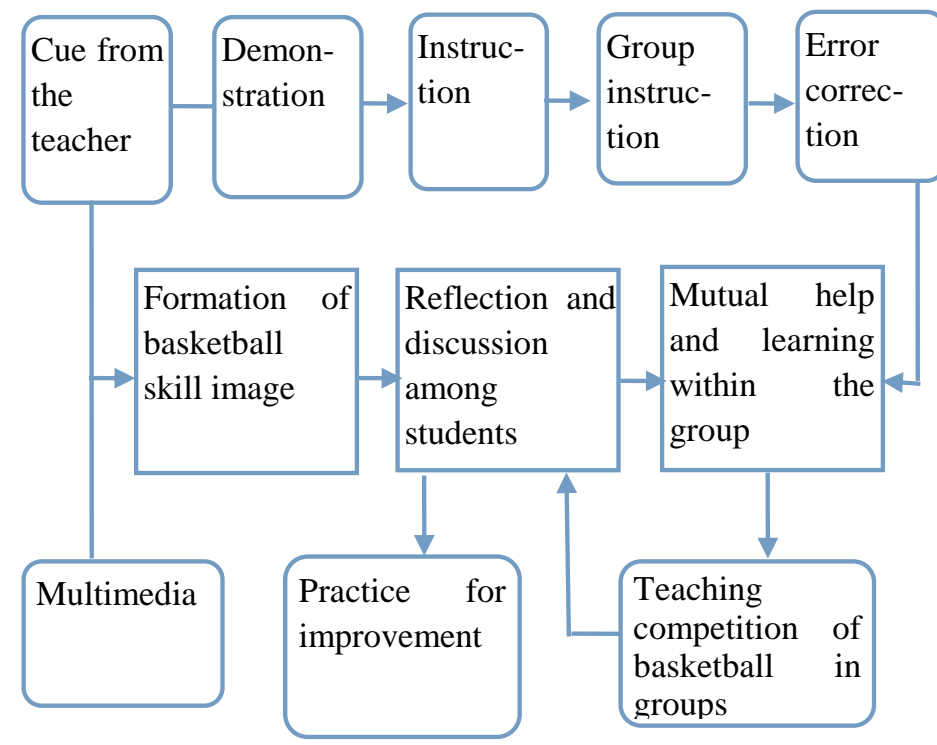

Figure 1. Teaching flowchart of cooperation learning teaching mode of optional basketball course

Figure 1 shows that the cooperation learning teaching mode is an organic combination of the technological learning and ability cultivation. Students could maximize their ability and learn basic knowledge, principles and skills of basketball by teachers' guidance and multimedia videos. Besides, the mutual learning and communication among students enable them to grasp the correct actions. In the teaching process, when encountering problems, students communicate with their groupmates and teachers, ask questions on the spot and get answers immediately. The cooperation learning teaching mode improves the relationship between teachers and students, which means that teachers focus more on guiding students to learn and practice rather than the control of teaching.

In the gymnasium of the Inner Mongolia Vocational College of Chemical Engineering, the experiment is carried out in accordance with the content of the required course provided by the syllabus of optional basketball course. The teaching content in the experimental group and control group is the same. Before the experiment, test the basic level of two groups by distributing the relevant questionnaire, including peer relations, collective cohesion, basic theoretical knowledge of basketball and the learning attitude of students. After the experiment, conduct field test of their basic basketball skills and then verify whether there is a significant difference with the open and fair evaluation rules. Besides, after the evaluation, the questionnaire is still distributed to test the difference between two groups in peer relations, collective cohesion, basic theoretical knowledge of basketball and the learning attitude of students. Experiment Note: teachers, teaching content, teaching hours, court and equipment of the two groups should be consistent; the test should be fair and impartial; the effective distribution and recovery of the questionnaire should be ensured.

\section{ANALYSIS OF EXPERIMENTAL RESULTS}

\subsection{Analysis of the Pre-test Results}

Students in the experimental group and control group never undergo any training of basketballrelated knowledge and skills. The pre-test indicators include peer relations (the degree of acceptance and being accepted), collective cohesion, basic theoretical knowledge of basketball and the learning attitude of students, which are implemented by the questionnaire and basketball-related paper, as shown in Table 1 and 2.

Table 1. Test results of the peer relations and collective cohesion of the experimental group and control group $(\overline{\mathrm{X}} \pm \mathrm{s}) \mathrm{n}=35$.

\begin{tabular}{|c|c|c|c|}
\hline peer relations & $\begin{array}{c}\text { Degree of } \\
\text { acceptance }\end{array}$ & $\begin{array}{c}\text { Degree of being } \\
\text { accepted }\end{array}$ & $\begin{array}{c}\text { Collective } \\
\text { cohesion }\end{array}$ \\
\hline $\begin{array}{c}\text { Experimental } \\
\text { group }\end{array}$ & $7.11 \pm 0.80$ & $6.94 \pm 0.80$ & $17.46 \pm 2.29$ \\
\hline Control group & $7.37 \pm 0.69$ & $6.97 \pm 0.75$ & $16.71 \pm 1.58$ \\
\hline $\mathrm{t}$ & -1.95 & -1.50 & 1.365 \\
\hline $\mathrm{p}$ & 0.059 & 0.881 & 0.181 \\
\hline
\end{tabular}

Table 2. Test results of theoretical knowledge and learning attitude of basketball in experimental group and control group $(\overline{\mathrm{X}} \pm \mathrm{s}) \mathrm{n}=35$.

\begin{tabular}{|c|c|c|c|c|}
\hline Test content & $\begin{array}{c}\text { Experimental } \\
\text { group }\end{array}$ & Control group & $\mathrm{t}$ & $\mathrm{p}$ \\
\hline $\begin{array}{c}\text { Theoretical } \\
\text { knowledge of } \\
\text { basketball }\end{array}$ & $47.03 \pm 11.49$ & $49.97 \pm 8.79$ & -1.505 & 0.141 \\
\hline $\begin{array}{c}\text { Learning } \\
\text { attitude }\end{array}$ & $16.00 \pm 2.43$ & $15.14 \pm 1.94$ & 1.840 & 0.075 \\
\hline
\end{tabular}

Table 1 shows that before the experiment there is no significant difference between the experimental group and control group in the peer relations (the degree of acceptance and being accepted) and collective cohesion, so they can be regarded as homogeneous.

Table 2 shows that there is no significant difference between the experimental group and control group in basketball related theoretical knowledge and learning attitude of students before the experiment, so the subjects of these two groupes are the same.

\subsection{Analysis of the Test Results after the Experiment}

When the teaching hours, court and equipment, teaching level of the two groupes are the same, the cooperation learning teaching mode is adopted in the experimental group, and while for the control group, the traditional teaching mode is used. After 4 months (one semester, a total of 32 group hours), analyze the changes in the relevant indicators, and then test the basketball skills of students, including shot within one minute and running jump shot. The test results 
are as shown in Table 3. Great significance exists between these two groups $(\mathrm{P}<0.01)$, indicating that the cooperation learning teaching mode has promoted students to acquire the basketball skills. Besides, the learning achievement in experimental group is superior to that in the control group and there is a very significant difference.

Table 3. Comparison of learning achievement of experimental group and control group after the experiment $(\bar{X} \pm s) n=35$.

\begin{tabular}{|c|c|c|c|c|}
\hline Test item & Group type & $\overline{\mathrm{X}} \pm \mathrm{s}$ & $\mathrm{t}$ & $\mathrm{p}$ \\
\hline \multirow{2}{*}{$\begin{array}{l}\text { Shot within in } \\
\text { one minute }\end{array}$} & $\begin{array}{l}\text { Experimental } \\
\text { group }\end{array}$ & $4.03 \pm 0.95$ & \multirow[t]{2}{*}{3.375} & \multirow[t]{2}{*}{$0.002 * *$} \\
\hline & Control group & $3.26 \pm 1.20$ & & \\
\hline \multirow{2}{*}{$\begin{array}{l}\text { Running jump } \\
\text { shot }\end{array}$} & $\begin{array}{l}\text { Experimental } \\
\text { group }\end{array}$ & $33.77 \pm 2.88$ & \multirow[t]{2}{*}{4.674} & \multirow[t]{2}{*}{$0.000 * *$} \\
\hline & Control group & $30.80 \pm 4$. & & \\
\hline \multirow{2}{*}{$\begin{array}{l}\text { Performance } \\
\text { of basketball } \\
\text { course }\end{array}$} & $\begin{array}{l}\text { Experimental } \\
\text { group }\end{array}$ & $85.17 \pm 3.79$ & \multirow[t]{2}{*}{8.056} & \multirow[t]{2}{*}{$0.000 * *$} \\
\hline & Control group & $75.03 \pm 5.67$ & & \\
\hline
\end{tabular}

$* *$ means $\mathrm{p}<.01$

Table 4. Test results of peer relations and collective cohesion of experimental group and control group $(\overline{\mathrm{X}} \pm \mathrm{s}) \mathrm{n}=35$.

\begin{tabular}{|c|c|c|c|}
\hline peer relations & $\begin{array}{c}\text { Degree of } \\
\text { acceptance }\end{array}$ & $\begin{array}{c}\text { Degree of being } \\
\text { accepted }\end{array}$ & $\begin{array}{c}\text { Collective } \\
\text { cohesion }\end{array}$ \\
\hline $\begin{array}{c}\text { Experimental } \\
\text { group }\end{array}$ & $8.69 \pm 1.81$ & $9.06 \pm 1.43$ & $21.57 \pm 3.35$ \\
\hline Control group & $6.80 \pm 1.51$ & $6.80 \pm 1.30$ & $17.43 \pm 2.67$ \\
\hline $\mathrm{t}$ & 3.721 & 6.660 & 6.389 \\
\hline $\mathrm{p}$ & $0.001^{* *}$ & $0.000^{* *}$ & $0.000^{* *}$ \\
\hline
\end{tabular}

$* *$ means $\mathrm{p}<.01$

Table 5. Test results of theoretical knowledge and learning attitude of basketball in experimental group and control group $(\overline{\mathrm{X}} \pm \mathrm{s}) \mathrm{n}=35$.

\begin{tabular}{|l|l|l|l|l|}
\hline Test content & $\begin{array}{l}\text { Experimental } \\
\text { group }\end{array}$ & Control group & $\mathrm{t}$ & $\mathrm{p}$ \\
\hline $\begin{array}{l}\text { Theoretical } \\
\text { knowledge of } \\
\text { basketball }\end{array}$ & $81.80 \pm 6.21$ & $73.09 \pm 5.98$ & 6.876 & $0.000^{* *}$ \\
\hline $\begin{array}{l}\text { Learning } \\
\text { attitude }\end{array}$ & $22.54 \pm 4.33$ & $18.03 \pm 4.67$ & 9.834 & $0.000^{* *}$ \\
\hline
\end{tabular}

$* *$ means $\mathrm{p}<.01$

After the basketball teaching experiment with the cooperation learning teaching mode is completed, continue to explore the difference between the experimental group and control group in peer relations, collective cohesion, theoretical knowledge of basketball and the learning attitude of students. As can be seen from table 4 and 5, the experimental group is superior to the control group in these four aspects, namely, a very significant difference exists $(\mathrm{P}<0.01)$. This indicates that the cooperation learning teaching mode has better teaching effect than the traditional one. The reason lies in that in the traditional teaching mode, teachers' management is emphasized rather that the active learning of students, while the cooperation learning teaching mode adopts the cooperative learning approach which could enhance the mutual communication and interaction among students. The mutual discussion, cooperation and assistance enable them to know each other and establish friendship; meanwhile, good learning atmosphere may stimulate their interest in basketball skills and knowledge.

\section{CONCLUSION}

The cooperation learning teaching mode is to make an organic combination of the cognitive abilities of students and teaching organizational skills. In addition to teaching students basketball skills, it cultivates their organizational abilities such as mutual assistance and communication. Compared with the traditional teaching mode, it is implemented based on the personality and psychological characteristics of students, which is conducive to culturing their subjectivity. This embodies the principle of individualized teaching and the basic characteristics of quality education. The research on the application of the cooperation learning teaching mode in the optional basketball course indicates that it is superior to the traditional teaching mode in many aspects. The group cooperation which wins the appreciation of students is adopted to mobilize their initiative for learning, so it plays an important role in improving the teaching quality. Besides, the implementation of the cooperation learning teaching mode effectively enhances students' basic knowledge and skills of basketball, for it could meet the inherent requirement of basketball and is in line with the skill learning laws. It is conducive to promoting the relations between students, enhancing the collective cohesion and changing their attitude towards sports. Colleges and universities should try to apply the cooperation learning teaching mode to the optional basketball course, and carry out training for teachers, aiming to improve the teaching effect of optional basketball course.

\section{REFERENCES}

[1] Yu Jin. Empirical Analysis of Cooperation Teaching in College Physical Education - An experimental study of Optional Basketball Course of Tonghua Normal University Science \& Technology Information, 2013 (28): 165-167.

[2] He Haijiang, Zhang Tiexiong. Application of Cooperative Learning Teaching Mode in Optional Gymnastics Course Sport Science \& Technology, 2010 (3): 29-30.

[3] Zhang Caichao. The Reflection and Prospect of the Application of Basketball Teaching in Basketball Teaching Journal of Guangzhou Sport University, 2013, 33 (4): 103105. 